\title{
Patents for invention: setting the stage for the British industrial revolution?
}

\author{
Christine MaCLEOD \\ University of Bristol \\ C.Macleod@bristol.ac.uk
}

Recibido: 26.05.2009

Aceptado: 02.11.2009

England came close to abolishing its nascent patent system a century and a half before the Industrial Revolution conventionally began ${ }^{1}$. In 1624, with popular anger erupting against the abuse of the royal prerogative to grant monopoly licences, which was enriching James I's courtiers and creditors, Parliament enacted the Statute of Monopolies (21 Jac.I c.3). Its purpose to prevent further such abuse, the Statute specifically preserved the monopoly privileges granted to inventors and to importers of invention. Section 6 limited patents of invention to a fourteen-year term, to «new manufactures within this realm», and to their «true and first inventor», excluding anything illegal or deemed harmful to the state or the public interest (MacLeod 1988: 14-19). For the next two and a quarter centuries, until the passage of the Patent Law Amendment Act of 1852, this clause of exemption provided the legislative basis of the English patent system. Are we to conclude that without this timely reprieve at the hands of enlightened members of parliament, England would have forfeited its opportunity to become «the first industrial nation»?

The importance of patents for economic development in general and for British industrialization in particular has been endorsed by no less an authority than Nobel laureate Douglass North: «by $1700 \ldots$ England had begun to protect private property in knowledge with its patent law. The stage was now set for the industrial revolution». (North \& Thomas 1973: 155-6; also North 1981: 164-6, Chang 2001). Harry Dutton's study of the English patent system in the century

${ }^{1}$ I wish to thank Alessandro Nuvolari (Scuola Superiore Sant» Anna, Pisa) and participants in the ESRC-sponsored seminar series on intellectual property law and history, organized by Graham Dutfield and Uma Suthersanen, at the School of Law, Queen Mary, University of London, in 2004, and in David Vaver's and Justine Pila's seminar on intellectual property law at the University of Oxford, in 2004-05, for their helpful comments on an earlier version of this paper.

EMPIRIA. Revista de Metodología de Ciencias Sociales. N. ${ }^{\circ}$ 18, julio-diciembre, 2009, pp. 37-58. ISSN: $1139-5737$ 
prior to its reform in 1852 lends influential support to North's views (Dutton 1984: 202-5), while Zorina Khan's research suggests that North's argument is more applicable to the United States» patent system than to England's (Khan 2005). Indeed, Khan and Kenneth Sokoloff contend that deficiencies in the patent system were actively responsible for nineteenth-century Britain's relatively poor economic performance (Khan and Sokoloff 1998: 292-313). Other scholars have been sceptical of any such direct relationship. T. S. Ashton, for example, considered that, «It is at least possible that even without the patent system, discovery might have developed just as rapidly as it did» (Ashton 1948: 10; also Plant 1934; Landes 1969: 64; Mathias 1969: 34; MacLeod 1988; Greasley \& Oxley 2007; and somewhat more ambiguously, Allen 2009). Most recently, economists Michele Boldrin and David K. Levine have issued a radical challenge to the value of all patent systems; their starting point, the paralysing effect of James Watt's patents on early steam engineering (Boldrin \& Levine 2008: 1$5)$.

\section{I}

The question posed in this paper is deceptively straightforward; the issues of definition and causality that it raises are many and complex. The biggest of them all is the nature of the industrial revolution, a question that economic historians have been debating for over a century with little sign of imminent closure. What exactly it was, when, where and how it occurred, and, of course, what caused it-such inter-related questions continue to fuel discussion. During the past three decades, there have been two major developments in the historiography of the industrial revolution. First, we have been required by the production of new sets of national income accounting figures to reconsider the pace and timing of change. The calculations of Nick Crafts and Knick Harley, in particular, suggest that the British economy grew more slowly before 1830 than previously thought: there was no «take-off», no sharp upturn in economic growth in the late eighteenth century. Instead, there was a gradual and slight acceleration, which slowly took the British economy to a new plane of activity: until the 1830s, GNP was growing at less than $2 \%$ per annum; GNP per head of population, at considerably less than $1 \%$ per annum (Crafts \& Harley 1992). Underlying this was a low rate of growth of productivity in manufacturing, with most of what there was, Crafts claims, concentrated in the cotton and iron industries: «not only was the triumph of ingenuity slow to come to full fruition, but it also does not seem appropriate to regard innovativeness as pervasive»(Crafts 1985: 85; cf. McCloskey 1981). Research on related topics has tended to support this less revolutionary, more evolutionary picture at a national level, although industrialization was undoubtedly faster and more visible at regional and local levels (Berg \& Hudson 1992; Coleman 1992: 36-42). Innovations took longer to diffuse than was once believed, so that it was the second half of the nineteenth century that witnessed the

EMPIRIA. Revista de Metodología de Ciencias Sociales. N. ${ }^{\circ}$ 18, julio-diciembre, 2009, pp. 37-58. ISSN: $1139-5737$ 
massive growth in steam power and in factory-based employment; while population grew continuously from the mid-eighteenth century, the standard of living only began to rise significantly from the 1860s (Musson 1976; Feinstein 1998).

The second major shift in perceptions of the industrial revolution involves a «globalization» of the phenomenon. Historians have been turning back to overseas trade and the «export economy» for explanations of Britain's early start. After several decades of privileging the home market and productivity increases in British agriculture, the explanatory focus is now returning to overseas markets, in particular the Atlantic economy; consequently, the controversial link between industrialization and the Atlantic slave trade has been revivified (Inikori 2002). Furthermore, the British case is being recast as part of the bigger question of why it was «the West» that led the way in economic development between the eighteenth century and the twentieth; how western Europe and North America overtook the previously predominant Asian centres of manufacturing output (and advanced technologies) in China and the Indian subcontinent. Studies that address this question take a broader geographical sweep and a longer chronological perspective (Pomeranz 2000). This also has the effect of reducing the prominence of that classic fifty year period, from 1780 to 1830, which is now less and less easily packaged as «the Industrial Revolution» (Pollard 1981; MacLeod 2004). Nonetheless, the term (its distinctiveness downplayed by lower case initial letters) continues to provide a convenient short-hand to refer to the first epoch in industrialization that promoted Britain's rise to economic predominance-to its becoming during the mid-nineteenth century «the workshop of the world», the leading producer and exporter of manufactured goods.

My title question, echoing North's emphasis on the patent system, implies that technological change played a significant causal role in the industrial revolution. Indeed, we are unlikely to proceed very far unless we allow that technological change was at least a necessary, if not a sufficient, condition for British industrialization. A succession of economic historians has put it at the heart of their explanations (for example, Mantoux 1928, Ashton 1948, Landes 1969, McCloskey 1981, Berg 1994, Mokyr 2002, Allen 2009), even if some, seeking to avoid anachronism, now re-describe it as «useful knowledge» and suggest that the customary emphasis on mechanization should be reformulated to include a wider range of techniques, capabilities, skills and «know-how». In Joel Mokyr's succinct formulation: «The key to the Industrial Revolution was technology, and technology is knowledge»(Mokyr 2002: 29). Moreover, whatever its initial role, it would be hard to deny that extensive technological change has been responsible for major increases in productivity during the past two centuries. For Mokyr indeed it is the sustained nature of this development that is crucial.

This leaves unresolved, however, the issue of which technological change. For the Victorians, it was simple: Britain's rise to global economic predominance rested on the mechanization of the cotton industry, coupled to the power of the steam engine. Peopled by heroic inventors, such as James Watt, Richard Arkwright, and John Kay, this Victorian grand narrative of the Industrial Revolution 
has become part of British national identity: it is enshrined in the national curriculum, it is one of the myths we live by (Coleman 1992: 36-42; MacLeod 2007: 1-4, 136-44). Were we to accept it, we could reduce the present question to whether, in the absence of a patent system, a few key inventions would still have been made: whether Watt would still have invented the separate condenser, Arkwright, the water-frame, and Kay, the flying shuttle.

It is no longer the case, however, that «whoever says industrial revolution, says cotton» (Hobsbawm 1962: 49-53). Nor, in the wake of research into the pace of its diffusion, are we inclined to allow the stationary steam engine the starring role allotted it by the Victorians-certainly, not before the middle of the nineteenth century. Until then the water-wheel continued to provide most mechanical power (Musson 1976, Von Tunzelmann 1978, Kanefsky 1979, Tann 1988, Crafts 2004). A less heroic view of the British industrial revolution has consistently proclaimed the importance of coal, as part of a long-term shift to fossil fuels that constituted a fundamental transition from a finite organic economy, based on land, wood and water, to an economy liberated from the constraints of land by its exploitation of the mineral resources beneath it. This interpretation of British industrialization as a gradual energy revolution that came to fruition in the mid-nineteenth century is not without its patents, but it has generally assumed a more incremental, more anonymous model of technological change (Nef 1932, Cipolla, 1962, Harris 1976, Flinn 1984, Thomas 1985, Wrigley 1988, Allen 2009).

Even less scope for patents is allowed by interpretations which emphasise the role played by some other technologies. Paulinyi (1986), for example, has made a case for the significance of machine tools as the crucial technology which, by producing «machines to make machines», opened the way for mass production: rarely patented, a stream of inventions to facilitate the cutting and shaping of metals emanated from the workshops of highly skilled craftsmen, a handful of whom are known to history, but most of whom remain anonymous and undervalued. For other historians the primary technological revolution was agricultural, not industrial: new crop rotations, new manures, selective breeding of animals, etc., raised the productivity of both land and labour to release a growing proportion of the workforce to find new employment in the industrial and service sectors (Bairoch 1973). Where not anonymous, technical advances such as these were rewarded rarely with patents, more often with prizes from agricultural and improvement societies, or they were protected by copyright in agrarian treatises (MacLeod 1988: 98, 193-5).

This raises a third issue: what is the model of invention to be adopted? The patent system is justified ultimately by an individualistic, not to say heroic, model of invention. Those who campaigned in the third quarter of the nineteenth century for the abolition of the patent system sought to undermine it by presenting an alternative, deterministic model of invention. The abolitionists denied that any individual inventor played an essential role. Technological change, they argued, had its own momentum, progressing incrementally through the

EMPIRIA. Revista de Metodología de Ciencias Sociales. N. ${ }^{\circ}$ 18, julio-diciembre, 2009, pp. 37-58. ISSN: 1139-5737 
accumulation of many inventive steps; in evidence they pointed to instances of simultaneous invention. Consequently, no one either merited the reward of a patent or needed the incentive of a patent to invent (MacLeod 1996: 137-54; MacLeod 2007: 264-76). It is, of course, an argument that has been rehearsed many times since, not least by Robert Merton and fellow sociologists in the midtwentieth century (McGee 1995). In Britain, however, the issue was resolved by the Patents, Designs and Trademarks Act of 1883, which, in reforming the system to make a patent accessible to many more inventors, effectively extinguished the abolitionists» cause. Simultaneously, elsewhere in Europe, the antipatent movement fizzled out as the Continent retreated from free trade. The Netherlands, which had abolished its patent system in 1869, returned to the fold in 1910, while Switzerland enacted its first federal patent law in 1887 (Penrose 1951: 15-16). And, although they continued to attract much criticism, the past century has witnessed the strengthening of patents, that is to say, their extension into more countries and new fields, with fewer exceptions allowed (Granstand 2005, May and Sell 2006, Dutfield 2009). I do not propose therefore to approach the question of this paper by exploring the theoretical case for and against technological determinism.

\section{II}

Instead, I shall focus on the nature and operation of the English patent system during the eighteenth and early nineteenth centuries, prior to its reform in 1852. First, I shall examine the long-term upward trend in patenting that begins in 1757 and coincides so neatly with the classic Industrial Revolution (Sullivan 1989). This will lead, second, to a critical investigation of how far the patent system may be taken as a proxy for inventive activity in this period-and thereby to an emphasis on the large amount of invention which was not captured by the patent statistics. Third, I shall suggest that to understand the workings of the patent system it is helpful to think of it as a technology in its own right: as with all technologies, it was shaped by the circumstances of its invention and development. It was a product of a period which was redefining property as being subject to exclusively private ownership, and to this «intellectual property» was no exception. Unless we recognise that a patent, first and foremost, created a piece of private property, we are missing the point. It had as much to do with investing as inventing; as much to do with capitalism as creativity.

As a preliminary, it is necessary to outline how the patent system operated. Before 1852 there was no dedicated Patent Office, only a tortuous route through the royal bureaucracy laid down by the Clerks Act (1535) for all grants of the crown under the great seal. An applicant delivered his petition for «letters patent» to one of the Secretaries of State, who referred it to the law officers (the Attorney General or the Solicitor General). Either law officer was required to check that the patent would not contravene the Statute of Monopolies; he was

EMPIRIA. Revista de Metodología de Ciencias Sociales. N. ${ }^{\circ}$ 18, julio-diciembre, 2009, pp. 37-58. ISSN: 1139-5737 
also expected to ensure that it would not harm the royal interest, for example, by reducing the revenue from excise duties. There was no formal examination for novelty or utility, and very few applications were refused. Having received the law officer's approval, however, the applicant still had to negotiate a bureaucratic maze. There was no further scrutiny of his invention, but his patent would not be enrolled until he had accumulated an expensive series of seals and signatures, paying fees and favours at every stage (Gomme 1946; MacLeod 1988: 40-8). It was this obstacle course that Charles Dickens famously lampooned in his «Poor Man's Tale of a Patent» and Little Dorrit (MacLeod 2007: 184-6). The process could be very time-consuming, especially for anyone not resident in London, and added to the cost. The diary of one Manchester inventor, for example, shows him spending six months in the capital during 1722-3, waiting on officials in order to secure his patent (Gomme 1934-5: 210-16). James Watt managed to reduce the time in London to two weeks, when he travelled down from Glasgow in 1768 to take the oath on his first patent (for the separate condenser), but the round-trip (returning via Birmingham) took him two months (Dickinson \& Jenkins: 30-2). To secure a patent for England and Wales cost approximately $£ 100$; to extend it to Scotland and Ireland, another $£ 200-250$ (plus more time and effort). Assistance from a patent agent, whose services the complexity of the system made increasingly essential, could add a further $£ 40$ to $£ 100$ (Dutton 1984: 86-96; Khan \& Sokoloff 1988: 300). This was a huge charge, at a time when a skilled worker earned about $£ 1$ to $£ 2$ per week. The only way Dickens's poor man could afford his patent was through that common Victorian literary device of a chance inheritance. Few inventors were so lucky; most had to look for rich partners and hope they found men of integrity.

There was still the specification to be filed. The requirement to specify the invention (normally within two to four months of the patent's enrolment) was introduced gradually during the first third of the eighteenth century; from 1734 it became standard. Although initially demanded to assist the law officers in discriminating among contemporaneous inventions that sounded similar, the specification was not normally scrutinized by any administrative department of government. As a result, many specifications remained extremely vague and cryptic (Macleod 1988: 48-55). Increasingly, however, they were subjected to close scrutiny when a prosecution for infringement reached the law courts. Indeed, the specification became the patent's most vulnerable aspect, as it was expected to disclose the invention accurately when required, but patentees might still try to limit such disclosures in the hope that that day would never arrive. There was also a course to steer between the Scylla of exactness that risked allowing pirates to infringe the patent through a minor variation and the Charybdis of too general a claim that would lead to the patent's invalidation if litigated (Adams \& Averley 1986: 156-79). It was anxiety concerning the validity of his specification that notoriously deterred James Watt from prosecuting infringements of his patent for the separate condenser. Fearful that his specification would be found insufficiently precise, for a long time he preferred not to risk losing his patent (Miller 2006). It

EMPIRIA. Revista de Metodología de Ciencias Sociales. N. ${ }^{\circ}$ 18, julio-diciembre, 2009, pp. 37-58. ISSN: 1139-5737 
also added to the costs of patenting. The need for a full and accurate specification that would withstand the test of litigation placed a premium on good draughtsmanship. One leading engineer in 1851 put the cost of patenting «a complex machine, or system of machines» at $£ 500-600$, because of having to provide extended and complicated specifications ([Select Committee] 1851: 429).

This leads to the enforcement of patent rights and the prosecution of infringements. Prior to 1753, a patentee could appeal to the monarch's Privy Council for support in the enforcement of his rights: infringement, if demonstrated, was deemed tantamount to contempt of the royal prerogative. It was always open to the Privy Council to refer a case to the civil jurisdiction of the common law courts; finally, prompted by an especially thorny case in 1752, it ceded its authority entirely to the courts (Hulme 1917; MacLeod 1988: 58-60). Patentees now had no resort but to the expense and delay of the legal system. The reluctance to prosecute engendered by these factors was exacerbated by the extreme uncertainty surrounding the law of patents. What constituted a patentable «invention» under the Statute of Monopolies only began to be determined once the Privy Council relinquished its jurisdiction in the mid-eighteenth century, and the case law was slow to compensate for the vagueness of an outdated statute. In 1795, Chief Justice Eyre, sitting in the case of Boulton and Watt vs Bull complained that «patent rights are nowhere that I can find accurately described in our books» (Holdsworth 1922-72: XI, 425). He was echoed three decades later, by a witness to parliament's first investigation since 1624 into the patent system, who told the 1829 select committee that «there being no existing basis of law, the dictum of the judge is one thing one day and another thing another». Or, in the pithier phrase of the engineer Marc Isambard Brunel's testimony to the same committee, «I might as well toss for the fate of a patent» ([Select Committee] 1829: 454, 486).

The imprecision and unpredictability of the law seems to have been exacerbated until the 1830s by a prejudice among judges and juries against patentees. Dutton refers to «the excessively hostile attitude of some judges» who, perhaps unsurprisingly in the historical and legal context, were on their guard against the abuse of the monopoly privilege that a patent conferred. They were regularly accused of interpreting the law in the strictest possible way, willing to cancel a patent for some trivial error of clerical copying (Dutton 1984: 77-8). Dutton finds that between 1750 and 1829 only a third of judgements at common law went in favour of the patentee. In the $1830 \mathrm{~s}$ and $1840 \mathrm{~s}$ this jumped to three-quarters (76\%), and judges themselves commented on the recent change in attitudes (Dutton 1984: 78-9; MacLeod 2007: 69-81, 183-9).

\section{III}

It is time to scrutinize the statistics. It is clear that, after a century of stagnation in which the annual total was normally in single figures and fluctuated be-

EMPIRIA. Revista de Metodología de Ciencias Sociales. N. ${ }^{\circ}$ 18, julio-diciembre, 2009, pp. 37-58. ISSN: $1139-5737$ 
tween zero and 23 , the 1760 s saw the beginning of a new trend-a long-term increase from an annual average of 20 in that decade to over 60 in the 1790 s, rising to more than 450 in the 1840s (Mitchell \& Deane 1962: 268-9; Sullivan 1989) ${ }^{2}$. How are we to interpret this? Does it reflect an upsurge in inventive activity? Is it evidence for a stimulus to invention from the patent system? Alternatively, is it indicative of nothing more than an increasing propensity to patent? This upturn coincides so neatly with the chronology of the classic Industrial Revolution that it almost seems churlish to question the extent to which it represents a real surge in inventive activity. It is ultimately impossible to demonstrate the case conclusively either way, but the case for its reflecting, at least in part, an increasing propensity to patent merits restatement (MacLeod 1988: 144-57). During this period the patent system was still an embryonic institution, one in course of development-indeed one still in search of a role. Although it was not subject to serious legislative interference between 1624 and 1852, it was highly plastic. Inventors only gradually became aware of the existence of a patent system and its potential relevance to them: patenting an invention was by no means common or automatic.

The patent system emerged from the seventeenth century deeply scarred both by its association with monopolies and royal favouritism and more recently by its implication in the stock-market bubble of the 1690s-a phenomenon repeated in 1717-20 (MacLeod 1986). Few inventors other than those with connections to either the royal court or the City of London were likely to have been aware of its existence; or if aware, to have seen its relevance to their activities. This began to change, but only slowly. Developments in transport and communication during the eighteenth century probably promoted awareness of the patent system at the same time as they stimulated the growth of a national market in commodities and in factors of production. In particular, faster coaching services and the regular publication of newspapers, journals, advertisements and other publicity materials carried news of patented inventions and patent litigation into the provinces. The 1790s saw the launch of specialist journals, such as the Repertory of Arts and Manufactures, which listed patents and critiqued new inventions. The broadening geographical distribution of patents is testimony to such an extension of awareness: it doubled from 19 counties where at least one patent was obtained in the 1750s to 38 counties in the 1790s (MacLeod 1988: 77-8, 126-7). A positive feedback mechanism appeared. The more patents issued, the greater was both the public's awareness of them and the pressure to obtain them. The patent system generated its own defensive logic: inventors began to realise that neglecting to patent an invention might mean losing it to someone more pro-active, who could then extract from them a payment for its employment or production. Such anxieties begin to appear in inventors» correspondence. One can see it, for example, informing the decisions of James Watt

2 Deflating the figures by population totals produces a much less impressive rate of increase before the 1830s: Khan and Sokoloff 1998: 299.

EMPIRIA. Revista de Metodología de Ciencias Sociales. N. ${ }^{\circ}$ 18, julio-diciembre, 2009, pp. 37-58. ISSN: $1139-5737$ 
and his friends as they debated whether or not to go to the expense of a patent (Dutton 1984: 183-5; MacLeod 1988: 89-90).

Other major trends increased the propensity to patent, not least the long-term restructuring of the economy, with its concomitant redirection of capital and labour from agriculture into the manufacturing and service sectors (Crafts 1985: 60-4). The agrarian sector, which had dominated the pre-industrial economy, generated few patents: while still employing over a third of the workforce in 1800, it accounted for less than 4 per cent of patents (MacLeod 1988: 97). Consequently, as employment in manufacturing and services expanded both absolutely and relatively during the eighteenth and nineteenth centuries, the pool of people with a higher propensity to patent grew. Another important trend conducive to patenting was urbanization (MacLeod 1988: 125-9) ${ }^{3}$. Since the vast majority of patentees were based in towns and cities, one might reasonably expect that the absolute and relative growth of Britain's urban population (19 per cent of total population in 1700, 23 per cent in 1750, 35 per cent in 1800,54 per cent in 1850) would likewise stimulate the propensity to patent.

Patenting was highly concentrated both geographically and by industry. Patentees clustered in those parts of the country and sectors of the economy that had moved furthest towards a hierarchical, competitive and capital-intensive economic structure. Throughout this period the patent system was dominated by Londoners: with approximately one tenth of England's population and one quarter of its manufacturing output, the capital city consistently obtained over half of all patents (Dutton 1984: 87-8; MacLeod 1988: 118-25). To some extent this reflects their proximity to the bureaucracy and knowledge of the system, but it is also symptomatic of the increasingly capitalistic organisation of London's manufacturing sector, in particular its higher-status crafts. A further quarter of English patents were taken out by residents of the manufacturing districts in the midlands and north-especially the metalworkers of Birmingham, the textile manufacturers of Lancashire and Yorkshire, and the hosiers of Nottingham and its region (Dutton 1984: 88-9; MacLeod 1988: 124-34).

In the second half of the eighteenth century the textile industries (including hosiery and lace) and the metalworking industries each accounted for approximately 14 per cent of English patents. It is surely not coincidental that this period saw major strides in the centralization and capitalization of these industries. The domestic organization that typified most of the textile industries had not been conducive to patenting: the diffusion of a manufacture over a wide area, often in remote cottages, made enforcement very difficult (as Kay had discovered when he tried to collect royalties from Lancashire weavers who were using the flying shuttle). Those sectors of the industry that were more centralized and highly capitalized tended to obtain more patents: the silk industry (with its ear-

3 Sokoloff remarked the same phenomenon in the early USA, though he ascribed higher levels of patenting in urban centres to higher rates of inventive activity (Sokoloff 1988, Sokoloff and Khan, 1990).

EMPIRIA. Revista de Metodología de Ciencias Sociales. N. ${ }^{\circ}$ 18, julio-diciembre, 2009, pp. 37-58. ISSN: 1139-5737 
ly «throwing» factories) and the finishing processes in all sectors were predominant in the patent records before 1770 . Thereafter, the reorganization of cotton and worsted spinning into factories prompted an upsurge in patents in those sectors. Not only was a patent easier to police in a factory-based industry, but it was also potentially more valuable as these industries grew exponentially (MacLeod 1988: 102-3). Khan and Sokoloff similarly emphasise the impetus from «centralized plant organization ... [to] more rapid technical change over time», and point to the greater prevalence of cottage manufacture in Britain as a major reason for its lower rate of productivity growth in comparison with the USA's (Khan \& Sokoloff 1998: 307-8). In the metal-ware trades, Birmingham outpaced all its rivals in obtaining patents: 90 by 1800. Simultaneously, it was distinguished by the highly capitalized structure of its enterprise: Birmingham's manufacturing was concentrated in fewer, richer, more competitive hands than that of its rivals (MacLeod 1988: 130; Berg 1991; Berg 1998). It is evident that the patent system had close links with industrialization, but these were not ones of simple cause and effect as implied by North. A patent was a form of property and an instrument of competition that was growing in value in an increasingly capitalistic, manufacturing economy. We might consider reversing the causal arrow, to suggest that industrialization stimulated patenting (see below, section V).

\section{IV}

It is doubtful that without a patent system eighteenth-century Britain would have seen significantly less inventive activity, since most inventors ignored it. Famous examples of unpatented inventions include Crompton's spinning mule and Trevithick's high-pressure steam engine. Some inventive activity is captured in the records of institutions such as the Royal Society of London and the Society of Arts, which from 1754 offered premiums and prizes for invention (MacLeod 1988: 193-5; Hilaire-Pérez 2000: 189-209; O’Brien et al. 1996). Most of it, however, was anonymous and is detectable only by its effects. Although often overlooked in assessments of patenting, the crucial importance of incremental improvements is widely acknowledged in both histories of industrialization and modern empirical studies of innovation (Landes 1969, Mathias 1969, David 1975, Rosenberg 1976, Von Tunzelmann 1981, Mokyr 1990, Freeman 1994). Technological change in major sectors of the economy raised their productivity or offered consumers a widening range of goods, on a scale that was scarcely hinted at in the patent records. Not least among examples of the former was the agricultural sector, responsible, as we have seen, for only 4 per cent of eighteenth-century patents. Yet, «between 1300 and 1800 the average yield of wheat rose from about 12 bushels per acre to about 20 bushels»; the output per acre of other crops realised similar or greater increases (Allen 2008: 182, Crafts 1985: 83-4). This 66 per cent growth in yields was achieved principally after 1600 , through the introduction of nitrogen-fixing crops in new rotations, which

EMPIRIA. Revista de Metodología de Ciencias Sociales. N. ${ }^{\circ}$ 18, julio-diciembre, 2009, pp. 37-58. ISSN: 1139-5737 
left no trace in the patent records. Also of importance in raising (both land and labour) productivity were improvements in drainage, seeds, and implements (Allen 2004: 202; Wrigley 1985). A small range of drainage devices and a few implements were patented, the latter mostly after 1780 -a development connected with the emergence of specialist manufacturers of agricultural implements-but their number was scarcely commensurate with the improvements in this sphere. Similarly, the gains made through selective breeding of livestock went unpatented.

The mining industry produced even fewer patents, despite growing in economic importance, its output expanding rapidly in volume and value. As mines became deeper and seams were worked further and further underground, a host of new technical challenges had to be met. Yet, the extraction of coal and ores scarcely featured in the patent records: only three patents were obtained for rock-boring tools or blasting techniques during the eighteenth century; only three for proposed solutions to the pressing problems of ventilation and «firedamp» (explosions). The productivity of the mining industry was raised in large part by the incremental adjustments to techniques practised by miners and skilled managers (known as «coal viewers»). Patentees were attracted instead to the solution of strictly mechanical problems in the mining industry-in particular, drainage and winding engines-that were visible on the surface, easily described, and represented a significant capital investment. A patent for such engines was both more easily policed and more marketable than the empirical improvements being devised underground (Flinn 1984: 74-128; MacLeod 1988: 100-2).

Despite, however, the relative prominence in the patent records of such mechanical devices, many of them powered by steam, there is evidence of extensive inventive activity in this sphere beyond the purview of the patent system. The phenomenon of «collective invention», first identified by Robert Allen in the Cleveland iron industry of north-eastern England in the period 1850-75, was also operating in the Cornish mining district during the first half of the nineteenth century. Alessandro Nuvolari argues that there it generated «a continuous and sustained flow of improvements in steam technology which in the end contributed to raising the thermodynamic efficiency of the steam engine» $(\mathrm{Nu}-$ volari 2004: 349). Harbouring a bitter resentment against Watt's extended patent for the separate condenser, Cornish engineers turned their back on the patent system. Cornwall's share of English patents for steam-related inventions fell from approximately 10 per cent in the eighteenth century to less than one per cent in the period 1813-52 (Nuvolari 2004: 358). Yet, this period witnessed Cornwall gain predominance in steam engineering. It started with Richard Trevithick and Arthur Woolf erecting (unpatented) high-pressure steam engines in Cornish tin and copper mines, where high coal prices made thermodynamic efficiency of particular concern. It also witnessed the launch of a monthly journal, Lean's Engine Reporter, by a group of mine managers with the intention of discovering and disseminating best-practice techniques. This publication was fundamental to the practice of collective invention in the Cornish mining industry, which ap-

EMPIRIA. Revista de Metodología de Ciencias Sociales. N. ${ }^{\circ}$ 18, julio-diciembre, 2009, pp. 37-58. ISSN: 1139-5737 
proximately doubled the «duty» of high-pressure engines in a quarter of a century.

Three essential features of collective invention identified by Allen and corroborated by Nuvolari are, first, the domination of technological change by incremental inventions; second, the sharing by firms of pertinent technical information concerning variations in design and performance; and third, the utilization by firms of this shared knowledge to improve the technology (Allen 1983, Nuvolari 2004). Both the complex and empirical nature of the technology and the diverse structure of the Cornish mining industry (where adventurers usually held shares in several mines) favoured the collective pursuit of improvements in the aggregate average performance of pumping engines. At the same time, the publication of these performance indicators allowed the best engineers, employed by the mines to erect and maintain their steam pumps, to demonstrate their capabilities and thereby enhance their professional reputations and career prospects.

There are distinct parallels here with the nascent civil engineering profession, which was responsible for many of the innovations in transport and communications that we commonly identify with the industrial revolution. Very little of the problem-solving activity that underpinned the engineering of bridges, tunnels, cuttings, embankments, etc, whether on roads, canals, or railways, is reflected in the patent records. Civil engineers tended to share and publish their solutions (MacLeod 1988: 104-5). Again, although not as systematic as the «collective invention» identified in Cornwall or Cleveland, a similar disregard for securing individual property in inventions is also visible among other successful innovative groups in this period, such as London's clock and instrument makers, some of the early developers of machine tools (others, however, practised secrecy) and the first generation of West Riding textile engineers studied by Gillian Cookson (1997: 8-9; MacLeod 1988: 104$5,112-13,188)$. In a related context, French researchers have remarked on the shared use of innovations in the technologically dynamic silk industry of Lyon, which crushed its London competitors with their reliance on patents and secrecy (Cottereau 1997, Foray \& Hilaire-Pérez 2006). These examples have led Nuvolari to suggest that «a regional or local perspective on innovation during the industrial revolution is likely to be the most fruitful research approach» (Nuvolari 2004: 362).

\section{V}

Finally, to turn the question on its head, we may consider whether the industrial revolution «set the stage» for the patent system. The English patent system was developed during the eighteenth and early nineteenth centuries at the behest of an enterprising minority who sought to maximize the profitability of its investment in inventive activity. It was shaped principally by the use they made

EMPIRIA. Revista de Metodología de Ciencias Sociales. N. ${ }^{\circ}$ 18, julio-diciembre, 2009, pp. 37-58. ISSN: 1139-5737 
(or attempted to make) of it and the response of the judiciary to their activities. Despite its creation of monopoly privileges, the routine administration of the English patent system was the epitome of laissez-faire. The government had no policy for industry, let alone for «technology» (an anachronism) or invention. It registered the inventor's claim and took his money, but left the question of his reward to the market and the business of regulating or enforcing the patent to the civil litigation of the courts.

The rising levels of capital investment in manufacturing industry that were at the heart of industrialization raised the financial stakes for entrepreneurs (Pollard 1964; Chapman 1970; Feinstein 1978; Cottrell 1980; Crafts 1985: 71-7; Tann 1988). Fixed assets in the relatively novel form of buildings and machinery, while opening the way to unprecedented levels of production and profit also exposed them to new risks: to losses from fire or interruptions of trade or strikes. The insurance industry was developed to offer some security against such risks as fire, and the legislature was mobilized to curtail the power of workers and to deter crimes against property (Supple 1980, Rule 1986, Pearson 2004).

Analogously, in the patent system such manufacturers saw an institution that would allow them to manage their investment in new technology-to secure their «property», and to exclude unauthorised intruders (Greasley \& Oxley 2007). «Few capitalists would invest in invention without the protection of a patent. Inventing was a risky activity and this kind of protection was the only realistic way of appropriating a return sufficient to cover the cost of producing and developing inventive output» (Dutton 1984: 151). It was primarily their interests that shaped the patent system in the two centuries before 1852 and arguably beyond. Their priority was not that of the present-day economist or legislature, concerned with finding the optimum trade-off between the stimulus to inventive activity and society's interest in widespread diffusion. Top of their agenda was the security of their investment and the development of institutions that would decrease the risk and uncertainty of managing it-primarily a cheap and fast way to settle disputes over the ownership and infringement of patents. This is evident in the proposals for reform of the system that were suggested before the mid-nineteenth century. In 1785, the cancellation of Arkwright's patent prompted a meeting in London of a number of patentees and a putative Patentees» Association to «unite in defence of their respective rights and to agree upon a mode of application to Parliament for the better security of their inventions» (Dutton 1984: 37) ${ }^{4}$. The «Thoughts upon Patents» and the «Doubts and Queries about Patents» drafted by James Watt around 1785 and 1795 respectively reflect many of the concerns that are repeatedly voiced in his correspondence with other patentees. Above all, he was anxious to protect patentees from the perils of infringement that resulted from the administrative weaknesses of the system and the uncertain state of the law. Unsurprisingly, his proposals focused primarily on

4 The quotation is from Birmingham City Archives, Boulton and Watt MSS, Watt to Matthews, 20.7.1785, Letter Book (Office Steam Engine).

EMPIRIA. Revista de Metodología de Ciencias Sociales. N. ${ }^{\circ}$ 18, julio-diciembre, 2009, pp. 37-58. ISSN: $1139-5737$ 
devising some means to reduce the problems inherent in specification (Robinson 1971). Two bills introduced into Parliament in 1820 and 1821 by a group of London inventors, engineers and manufacturers proposed a range of administrative reforms to strengthen the patentee's position, including «protection during experimentation; a body of commissioners consisting of engineers and scientists; the amendment of small errors in the specification; and a published list of existing patents» (Dutton 1984: 42). The growing pressure for reform from 1825 led the government to appoint a select committee on the law of patents in 1829 . The evidence it heard identified four principal problems: three of them concerned the inadequacies of patent protection; the fourth, the expense of patenting (Dutton 1984: 42-5).

This was the first time that reducing the cost of patents had reached the official agenda, and even then none of the witnesses made a strong case in its favour. Indeed, the engineers Marc Isambard Brunel and John Farey both argued against any reduction, on the grounds that it would spawn patents for «trivial» inventions, which would be used to harass industrialists with demands for royalties (Dutton 1984: 45). Isambard Kingdom Brunel, proposing the patent system's abolition to the 1851 select committee, echoed his father's argument: a patent in the hands of a workman was a nuisance both to industrialists and, did he but realize it, a danger to the patentee himself (MacLeod 1996: 145-50). By 1851, the cost of a patent had become a serious concern for reformers, and it would provoke much debate for the rest of the century, as the Victorians, ever fearful of the system being swamped by trivia, nonetheless fretted whether valuable inventions were being lost to the public through the impecuniousness of working-class inventors.

Indicative, by contrast, of the oligarchic nature of the eighteenth-century patent system (and the section of society which shaped it) was the fact that patentees had not complained of the cost, only of the poor value for money of their insecure investment. They had been happy for the patent system to remain an exclusive club. Its social bias was sufficiently marked to prompt the head of the judiciary, Lord Chancellor Kenyon, while finding in favour of Boulton and Watt in 1799, to confess to some disquiet: «it struck him that there was a great deal of oppression of the lower orders of men from patents, by those who were more opulent» (Robinson 1971: 137) ${ }^{5}$.

Patenting was for sharks, not for minnows. Until 1852 an English patent cost the equivalent of one to two years» wages for a skilled working man. Khan and Sokoloff emphasise the high cost of British patents in comparison with the United States». Their analyses demonstrate that not only were «English patentees more likely to be from the relatively elite classes («gentlemen», merchants, and professionals) than their U.S. counterparts», but also that the rate of patenting per head of population jumped in the US during the early nineteenth century as the social composition of patentees broadened. They conclude that «the op-

\footnotetext{
5 The quotation is from The Times Law Report, 26 January 1799.
} 
eration of the patent system in England discouraged many inventors or would-be inventors from participation in the system» (Khan \& Sokoloff 1998: 305; MacLeod 1991). The sensitivity of patenting to cost was clearly shown when the initial fee for a UK patent was reduced to $£ 25$ in 1852: the number of patents leapt from the 455 issued in 1851 to 2,113 in 1853 . Following a further reduction to $£ 4$ in 1883 , the annual total more than doubled during that decade, from approximately 4,000 to approximately 10,000 per annum (Boehm and Silberston 1967: 22-3, 32-4; Khan and Sokoloff 1998: 299). Even then, many inventors disregarded the patent system, finding other, more appropriate means for exploiting their invention (Moser 2005).

\section{VI}

In conclusion, Britain got the patent system it deserved. That is to say, the specific characteristics of Britain's patent system were moulded by the circumstances of its development: an oligarchic society produced an oligarchic patent system. Most eighteenth-century inventors were either ignorant of its existence or found it too expensive or inconvenient to buy and enforce a patent. Many could see no benefit from patenting their invention in the particular circumstances in which they intended to use it. Instead, they deployed it unobtrusively in their own business, or engaged in «open» collective invention. Some retained ethical misgivings about appropriating an invention for personal gain, and others still perceived technical change as a phenomenon subject to divine intervention or «Providence», for which no individual merited reward (MacLeod 1988: 202-4, 219-20). Only a small minority calculated that a patent would be a good commercial investment, or that it would be perilous not to obtain one because of the risk of pre-emption. A patent established a temporary monopoly over something one wanted to sell-whether that was control of the invention, a licence to use it, or a distinctive product. The conditions for such a market in invention were only in their infancy in eighteenth-century Britain, and the patent system was developed by commercially minded men in order to promote it. This period witnessed market-orientated inventors and investors suffering many frustrations and set-backs as they attempted to educate the government and the judiciary in the role they conceived a patent system should play.

With a patent system more in the mould of its more democratic US counterpart, Britain might have enjoyed not only a faster rate of economic growth (through higher rates of invention and its diffusion), but also a greater degree of social mobility, thanks to widened opportunities for the commercialization of inventions (Khan \& Sokoloff 1998: 306). However, it would have required a different type of society to produce such a patent system. On the other hand, without any patent system at all, the evidence of widespread inventive activity suggests that British inventors would have continued to invent. Greater problems

EMPIRIA. Revista de Metodología de Ciencias Sociales. N. ${ }^{\circ}$ 18, julio-diciembre, 2009, pp. 37-58. ISSN: $1139-5737$ 
might have arisen, however, in raising investment capital to develop and commercialise their more capital-intensive inventions without some institutional protection to offer to their financial supporters. It seems unlikely that, without a patent system, the industrial revolution would have happened exactly as it did, but the wider and deeper pressures towards industrialization throughout the western hemisphere at this period imply that it would have occurred in some form, somewhere, soon-most probably in Britain (Allen 2009).

\section{BIBLIOGRAPHY}

AdAms, John N., and Averley, Gwen (1986), «The patent specification, the role of Liardet v Johnson», Journal of Legal History, 7, 156-79.

Allen, R. C. (1983), «Collective invention», Journal of Economic Behavior and Organization, 4, 1-24.

ALLEN, R. C. (2008), «The nitrogen hypothesis and the English agricultural revolution: a biological analysis», Journal of Economic History, 68, 182-210.

Allen, R. C. (2009), The British Industrial Revolution in Global Perspective, Cambridge: Cambridge University Press.

Ashton, T. S. (1948), The industrial revolution, 1760-1830, Oxford and New York: Oxford University Press.

BAIROCH, Paul (1973), «Agriculture and the industrial revolution, 1700-1914», in Carlo Cipolla (ed.), The Fontana economic history of Europe, vol. 3, London: Collins/Fontana.

BERG, Maxine (1991) «Commerce and creativity in eighteenth-century Birmingham», in Maxine Berg (ed.), Markets and manufacture in early industrial Europe, London: Routledge.

BERG, Maxine (1998), «Product innovation in core consumer industries in eighteenthcentury Britain», in Maxine Berg and Kristine Bruland (eds.), Technological revolutions in Europe, historical perspectives, Cheltenham and Northampton, MA.: Edward Elgar, 138-60.

BERG, Maxine (1994), The age of manufactures, 1780-1820: industry, innovation and work in Britain, $2^{\text {nd }}$ edn, London and New York: Routledge.

BERG, Maxine, and HudSON, Patricia (1992), «Rehabilitating the industrial revolution», Economic History Review, 45, 24-50.

Boldrin, Michele, and Levine, David K. (2008), Against intellectual monopoly, Cambridge: Cambridge University Press.

CANNADINE, David (1984), «The present and the past in the English industrial revolution», Past \& Present, 103, 131-72.

CHANG, H-J. (2001), «Intellectual property rights and economic development: historical lessons and emerging issues», Journal of Human Development, 2, 287-309.

Chapman, S. D. (1970), «Fixed capital formation in the British cotton industry, 17701815», Economic History Review, 23, 235-66.

Cipolla, Carlo M. (1962), The Economic History of World Population, Harmondsworth: Penguin Books.

Coleman, D. C. (1992), Myth, history and the industrial revolution, London and Rio Grande: The Hambledon Press.

EMPIRIA. Revista de Metodología de Ciencias Sociales. N. ${ }^{\circ}$ 18, julio-diciembre, 2009, pp. 37-58. ISSN: $1139-5737$ 
CoOKson, Gillian (1997), «Family firms and business networks: textile engineering in Yorkshire, 1780-1830», Business History, 39, 1-20.

CotTEREAU, Alain (1997), «The fate of collective manufactures in the industrial world: the silk industries of Lyons and London, 1800-1850», in C. Sabel and J. Zeitlin (eds.), Worlds of possibilities , Cambridge: Cambridge University Press, 75-152.

COTTRELL, Philip L. (1980), Industrial finance, 1830-1914: the finance and organization of English manufacturing industry, London: Methuen.

CrafTS, N. F. R. (1985), British economic growth during the industrial revolution, Oxford: Clarendon Press.

CRAFTS, N. F. R. (2004), «Steam as a general technology: a growth accounting perspective», Economic Journal, 114, 338-51.

CRAFTS, N. F. R. and Harley, C. K. (1992), «Output growth and the British industrial revolution: a restatement of the Crafts-Harley view», Economic History Review, 45, 70330.

DAVID, Paul A. (1975), Technical choice, innovation and economic growth, Cambridge: Cambridge University Press.

DiCKENS, Charles (1850), «A poor man's tale of a patent», Household Words, 19 October 1850, 73-5.

DickENs, Charles (1967), Little Dorrit, Harmondsworth: Penguin Books.

Dickinson, H. W. and Jenkins, Rhys (1981), James Watt and the steam engine, with introduction by Jennifer Tann, $2^{\text {nd }}$ edn, Ashbourne: Moorland.

DUTFIELD, Graham (2009), Intellectual property rights and the life science industries, past, present and future, $2^{\text {nd }}$ edn, London: World Scientific.

DutTon, H. I. (1984), The patent system and inventive activity during the industrial revolution, Manchester: Manchester University Press.

FeInsteIn, Charles H. (1978), «Capital formation in Great Britain», in Peter Mathias and M. M. Postan (eds.), Cambridge Economic History of Europe, vol. 7, pt 1, Cambridge: Cambridge University Press, 28-96.

FEINSTEIN, C. H. (1998), «Pessimism perpetuated: real wages and the standard of living in Britain during and after the industrial revolution», Journal of Economic History, $58,625-58$.

FuINN, Michael (1984), The history of the British coal industry, 1700-1830, Oxford: Clarendon Press.

ForAY, Dominique, and HILAIRE-PÉREZ, Liliane (2006), «The economics of open technology: collective organisation and individual claims in the «fabrique lyonnaise» during the Old Regime», in Cristiano Antonelli et al (eds.), New frontiers in the economics of innovation and new technology: essays in honor of Paul A. David, Cheltenham and Northampton, MA: Edward Elgar.

FREEMAN, Christopher (1994), «The economics of technical change», Cambridge Journal of Economics, 18, 463-514.

Gomme, A. A. (1934-5), «Patent practice in the eighteenth century: the diary of Samuel Taylor, threadmaker and inventor, 1722-3», Transactions of the Newcomen Society, $15,210-16$.

Gomme, Allan A. (1946) Patents of invention: origin and growth of the patent system in Britain, London: Longmans Green for the British Council.

GRANSTAND, O. (2005), «Innovation and intellectual property rights», in Jan Fagerberg, D. C. Mowery and R. R. Nelson (eds.), The Oxford handbook of innovation, Oxford and New York: Oxford University Press. 
GREASLEY, David, and OXLEY, Les (2007), «Patenting, intellectual property rights and sectoral outputs in industrial revolution Britain, 1780-1851», Journal of Econometrics, 139, 340-54.

HARRIS, J. R. (1976), «Skills, coal, and British industry in the eighteenth century», History, $61,167-82$.

HilaIRE-PÉREZ, Liliane (2000), L'invention technique au siècle des Lumières, Paris: Albin Michel.

HoBSBAWM, Eric J. (1962), The age of revolution, 1789-1848, London: Weidenfeld and Nicolson.

HoldsworTh, W. (1922-72), A history of English law, 17 vols., London: Methuen.

Hulme, E. W. (1917), «Privy Council law and practice of letters patent for invention from the Restoration to 1794», Law Quarterly Review, 33, 63-75, 181-95.

INIKORI, Joseph E. (2002), Africans and the industrial revolution in England, Cambridge: Cambridge University Press.

KANEFSKY, J. W. (1979), «The diffusion of power technology in British industry, 1760$1870 »$, unpubl. PhD thesis, University of Exeter.

KHAN, B. Zorina (2005), The democratization of invention: patents and copyrights in American economic development, 1790-1920, Cambridge: Cambridge University Press.

KHAN, B. Zorina and SoKoloff, Kenneth L. (1998), «Patent institutions, industrial organization and early technological change: Britain and the United States, 17901850», in Maxine Berg and Kristine Bruland (eds.), Technological revolutions in Europe, historical perspectives, Cheltenham and Northampton, MA.: Edward Elgar, 292-313.

LANDES, David S. (1969), The unbound Prometheus: technological change and industrial developments in western Europe, from 1760 to the present, Cambridge: Cambridge University Press.

McCloskey, D. N. (1981), «The industrial revolution, 1780-1860: a survey», in Roderick Floud and D. N. McCloskey (eds.), The economic history of Britain since 1700, vol. I, Cambridge: Cambridge University Press, 103-27.

McGeE, David (1995), «Making up mind: the early sociology of invention», Technology and Culture, 36, 773-801.

MACLEOD, Christine (1986), «The 1690s patents boom: invention or stock-jobbing?», Economic History Society, 39, 549-71.

MACLEOD, Christine (1988) Inventing the industrial revolution: the English patent system, 1660-1800, Cambridge: Cambridge University Press.

MACLEOD, Christine (1991), «The paradox of patenting: invention and its diffusion in $18^{\text {th}}$ - and $19^{\text {th }}$-century Britain, France, and North America», Technology and Culture, 32, 885-910.

MACLEOD, Christine (1996), «Concepts of invention and the patent controversy in Victorian Britain», in Robert Fox (ed.), Technological change: methods and themes in the history of technology, Amsterdam: Harwood Academic Publishers, 137-54.

MACLEOD, Christine (2004), «The European origins of British technological predominance», in L. Prados de la Escosura (ed.), Exceptionalism and industrialisation: Britain and its European rivals, 1688-1815, Cambridge: Cambridge University Press, 111-26.

MACLEOD, Christine (2007), Heroes of invention: technology, liberalism and British identity, 1750-1914, Cambridge: Cambridge University Press. 
MacLeod, Christine, and Nuvolari, Alessandro (2008), «Inventive activities, patents and early industrialization: a synthesis of research issues», mimeo.

Mantoux, Paul (1928), The industrial revolution in the eighteenth century: an outline of the beginnings of the modern factory system in England, trans, Marjorie Vernon, London: Jonathan Cape.

Mathias, Peter (1969), The first industrial nation: an economic history of Britain, 17001914, London, Methuen.

MAY, Christopher, and Sell, Susan (2006), Intellectual property: a critical history, Boulder: Lynne Rieder.

MILLER, David P. (2006), «Watt in court: specifying steam engines and classifying engineers in the patent trials of the 1790s», History of Technology, 27, 43-76.

Mitchell, B. R., and Deane, Phyllis (1962), Abstract of British historical statistics, Cambridge: Cambridge University Press

MOKYR, Joel (1990), The lever of riches: technological creativity and economic progress, Oxford and New York: Oxford University Press.

MокYR, Joel (2002), The gifts of Athena: historical origins of the knowledge economy, Princeton and Oxford: Princeton University Press.

Moser, Petra (2005), «How do patent laws influence innovation? Evidence from nineteenth-century world fairs», American Economic Review, 95, 1213-36.

Musson, A. E. (1976), «Industrial motive power in the United Kingdom, 1800-1870», Economic History Review, 29, 415-39.

Nef, J. U. (1932), The rise of the British coal industry, London: G. Routledge \& Sons.

NorTh, Douglass C. (1981), Structure and change in economic history, New York and London: W. W. Norton.

North, Douglass C. and ThOMAs, Robert P. (1973), The rise of the western world: a new economic history, Cambridge: Cambridge University Press.

NuvolaRI, Alessandro (2004), «Collective invention during the British industrial revolution: the case of the Cornish pumping engine», Cambridge Journal of Economics, $28,347-63$.

PaulinYI, A. (1986), «Revolution and technology», in Roy Porter and Mikulas Teich (eds.), Revolution in history, Cambridge: Cambridge University Press.

PEARSON, Robin (2004), Insuring the industrial revolution: fire insurance in Great Britain, 1700-1850, Aldershot: Ashgate.

Penrose, Edith Tilton (1951), The economics of the international patent system, Baltimore, Johns Hopkins.

Plant, Arnold (1934), «The economic theory concerning patents for inventions», Economica, n.s. 1, 30-51.

POLLARD, Sydney (1964), «Fixed capital in the industrial revolution in Britain», Journal of Economic History, 24, 299-314.

Pollard, Sydney (1981), Peaceful conquest: the industrialization of Europe, 17601970, Oxford: Oxford University Press.

POMERANZ, Kenneth (2000), The great divergence: Europe, China and the making of the modern world economy, Princeton, NJ: Princeton University Press.

RoBINSON, Eric (1971), «James Watt and the law of patents», Technology and Culture, 12, 115-39.

Rosenberg, Nathan (1976), Perspectives on technology, Cambridge: Cambridge University Press.

EMPIRIA. Revista de Metodología de Ciencias Sociales. N. ${ }^{\circ}$ 18, julio-diciembre, 2009, pp. 37-58. ISSN: 1139-5737 
RULE, John (1986), The labouring classes in early industrial England, 1750-1850, London: Longman.

SAMUEL, Raphael (1977), «Workshop of the world: steam power and hand technology in mid Victorian Britain», History Workshop Journal, 3, 6-72.

SCHIFF, Eric (1971), Industrialization without national patents: the Netherlands 18691912; Switzerland, 1850-1907, Princeton: Princeton University Press.

[Select Committee] (1829), Report from the Select Committee appointed to inquire into the present state of the Law and Practice relative to the granting of Patents for Inventions, British Parliamentary Papers 1829 (332), III.

[Select Committee] (1851), Report and Minutes of Evidence taken before the Select Committee of the House of Lords appointed to consider of the Bill for the amendment of the Law touching Letters Patent for Inventions, British Parliamentary Papers 1851 (486), XVIII.

SOKOLOFF, Kenneth L. (1988), «Inventive activity in early industrial America: evidence from patent records, 1790-1846», Journal of Economic History, 48, 813-50.

SoKOLOFF, Kenneth L., and KHAN, B. Zorina (1990), «The democratization of invention during early industrialization: evidence from the United States, 1790-1846», Journal of Economic History, 50, 363-78.

Sullivan, Richard J. (1989), «England's «Age of Invention»: the acceleration of patents and of patentable invention during the industrial revolution», Explorations in Economic History, 26, 424-52.

Supple, Barry E. (1970), The Royal Exchange Assurance: a history of British insurance, 1720-1970 , Cambridge: Cambridge University Press.

TANN, Jennifer (1988), «Fixed capital formation in steam power», in Charles H. Feinstein and Sidney Pollard (eds.), Studies in capital formation, 1750-1920, Oxford: Clarendon Press, 164-81.

THOMAS, Brinley (1985), «Escaping from constraints: the industrial revolution in a Malthusian context», Journal of Interdisciplinary History, 15, 729-53.

Von Tunzelmann, G. N. (1978), Steam power and British industrialization to 1860, Oxford: Clarendon Press.

Von TunzelmanN, G. N. (1981), «Technical progress during the industrial revolution», in Roderick Floud and D. N. McCloskey (eds.), The economic history of Britain since 1700, vol. I, Cambridge: Cambridge University Press, 143-63.

Vотн, H. J. (1998), «Time and work in eighteenth-century London», Journal of Economic History, 28, 29-58.

Wrigley, E. A. (1985), «Urban growth and agricultural change: England and the Continent in the early modern period», Journal of Interdisciplinary History, 15, 683728.

Wrigley, E. A. (1988), Continuity, chance and change: the character of the industrial revolution in Britain, Cambridge: Cambridge University Press.

\section{RESUMEN}

La importancia de las patentes para el desarrollo económico en general y para la industrialización inglesa en particular sigue siendo una cuestión sin resolver a pesar de la intensa investigación histórica que ha tenido lugar en los úl-

EMPIRIA. Revista de Metodología de Ciencias Sociales. N. ${ }^{\circ}$ 18, julio-diciembre, 2009, pp. 37-58. ISSN: $1139-5737$ 
timos veinticinco años. Este artículo reexamina este debate a la luz de estas investigaciones y de la historia revisionista de la revolución industrial inglesa. El artículo se centra en la naturaleza y en el funcionamiento del sistema de patentes inglés durante el siglo XVIII y parte del siglo XIX, concretamente hasta la reforma de 1852. En primer lugar se reinterpreta la tendencia al alza en el número de patentes desde 1762 y coincidiendo con los supuestos años clásicos de la revolución industrial. En segundo lugar, se investiga que parte de la actividad inventiva tuvo lugar fuera del sistema de patentes, esto es, no fue capturado en las estadísticas. En tercer lugar, se sugiere que debemos pensar en el sistema de patentes como una tecnología que, como cualquier otra, fue conformada por las circunstancias en que tuvo lugar su invención y desarrollo. Este sistema fue el producto de un periodo en el que la propiedad se redefinió como un derecho privado exclusivo. A menos que reconozcamos que una patente crea, ante todo, un derecho de propiedad privada estaremos equivocando el punto de vista. Las patentes tenían que ver tanto con la inversión como con la invención. En conclusión, este artículo revierte el famoso argumento de Douglass North, y ofrece, en su lugar, el argumento de que fue la revolución industrial la que creó el marco para el surgimiento del sistema de patentes.

\title{
PALABRAS CLAVE
}

Patentes, revolución industrial, propiedad industrial, invención colectiva.

\begin{abstract}
The importance of patents for economic development in general and for British industrialization in particular remains an unresolved issue, but one that during the past twenty-five years has benefited from intensive historical research. This paper re-examines the debate in the light both of that research and of revisionist histories of the British industrial revolution. It focuses on the nature and operation of the English patent system during the eighteenth and early nineteenth centuries, prior to its reform in 1852. First, it re-examines the upward trend in patenting that begins in 1762 and coincides neatly but deceptively with the classic industrial revolution. Second, it investigates how much inventive activity was conducted beyond the patent system and is consequently not captured by the patent statistics. Third, it suggests we should think of the patent system as a technology in its own right: as with all technologies, it was shaped by the circumstances of its invention and development. It was a product of a period that was redefining property as subject to exclusively private ownership, and to this «intellectual property» was no exception. Unless we recognise that a patent, first and foremost, created a piece of private property, we are missing the point. Patenting had at least as much to do with investing as inventing; as much to do
\end{abstract}

EMPIRIA. Revista de Metodología de Ciencias Sociales. N. ${ }^{\circ}$ 18, julio-diciembre, 2009, pp. 37-58. ISSN: $1139-5737$ 
with capitalism as creativity. In conclusion, the paper reverses Douglass North's famous causal claim, arguing instead that the industrial revolution «set the stage» for the patent system.

\section{KEYWORDS}

Patents, industrial revolution, intellectual property, collective invention. 